\title{
Reproductive cycles of the southern banded guitarfish Zapteryx xyster and the Velez ray Raja velezi caught as bycatch in a bottom-trawl fishery
}

\author{
Juan Carlos Azofeifa-Solano ${ }^{1}$, Tayler M. Clarke ${ }^{2}$, Mario Espinoza ${ }^{1,3}$ \& Ingo S. Wehrtmann ${ }^{1,3}$ \\ ${ }^{1}$ Unidad de Investigación Pesquera y Acuicultura, Centro de Investigación en Ciencias del Mar y Limnología \\ Universidad de Costa Rica, San José, Costa Rica \\ ${ }^{2}$ Changing Ocean Research Unit, Institute for the Oceans and Fisheries, University of British Columbia \\ Vancouver, Canada \\ ${ }^{3}$ Escuela de Biología, Universidad de Costa Rica, San José, Costa Rica \\ Corresponding author: Ingo S. Wehrtmann (ingowehrtmann@gmx.de)
}

\begin{abstract}
The southern banded guitarfish, Zapteryx xyster, and the Velez ray, Raja velezi, are two endemic elasmobranchs in the eastern Tropical Pacific that are commonly caught by the bottom-trawl fishery. Reproductive cycles of these batoids were inferred from the hepatosomatic and gonadosomatic indexes (males and females) and the oviductal gland width and the yolk follicle diameter (females) of mature specimens collected along the Pacific of Costa Rica between 2010 and 2011. Z. xyster females have a partially defined annual cycle with one reproductive peak in June and July, with most neonates and gravid females occurring during December and January (beginning of the dry season). The gestation period of Z. xyster can range between four and six months; males are probably capable of mating continuously throughout the year. Females and males of $R$. velezi have a continuous reproductive cycle with no clear peaks. Management and conservation measures of these batoids should consider their reproductive ecology, which may be linked to the degree of vulnerability to fishing. Based on our findings, we recommend reducing fishing pressure when mating (June-July) and pupping (December-January) of Z. xyster occur. In contrast, a reduction of fishing pressure on previously identified nursery grounds of $R$. velezi in the southern Pacific of Costa Rica may benefit their population.
\end{abstract}

Keywords: Zapteryx xyster; Raja velezi; Batoidea; reproductive cycle; bottom-dwelling elasmobrachs; eastern Tropical Pacific

\section{INTRODUCTION}

Life history information can help identify vulnerable elasmobranch species and develop effective conservation and management measures (Hoenig \& Gruber 1990, Morgan \& Hoenig 1997, Goldman et al. 2012, Awruch 2013, Rigby et al. 2016). Given that a quarter of all chondrichthyans species are currently threatened with extinction, conservation measures for this group have become a top priority (Dulvy et al. 2014, Davidson et al. 2015). Some of the main threats affecting elasmobranchs, such as overfishing and habitat degradation, are concentrated in coastal areas (Ferretti et al. 2010, Graham et al. 2010, Ward-Paige et al. 2010, Costello et al. 2012, Worm et al. 2013, Davidson et al. 2015, Spaet et al. 2016). Consequently, elasmobranchs that inhabit these coastal areas, remar- kably large and slow-moving species like stingrays and guitarfishes, are among the most threatened (Dulvy et al. 2014), whether it is during their entire life cycle or vulnerable stages (Heupel et al. 2007, Jirik \& Lowe 2012, Tobin et al. 2014, Chapman et al. 2015). Knowledge of their reproductive cycle can provide useful information to minimize their populations' impacts during vulnerable phases like mating or pupping (Hoenig \& Gruber 1990, Awruch 2013).

Fisheries in the eastern Tropical Pacific (ETP) have been poorly managed, in part due to a lack of ecological and biological information and unreliable or nonexistent catch and landing data. However, the weak fisheries management framework also plays a significant role (Clarke et al. 2016, 2018, Espinoza et al. 2018). The Costa Rican Pacific is home to 93 elasmobranch species, of which $15 \%$ are threatened, and

Corresponding editor: Yassir Torres 
41\% are data deficient (Espinoza et al. 2018). Like other regions, most elasmobranchs in Costa Rica have a high degree of overlap with coastal and pelagic fisheries, some of which operate at unsustainable fishing levels (Whoriskey et al. 2011, Dapp et al. 2013, Davidson et al. 2015, Clarke et al. 2018). Over 35\% of the elasmobranch species caught along the Costa Rican Pacific correspond to bycatch of the commercial bottom-trawl fishery (Bussing \& López 2009, Clarke et al. 2016, 2018). Two of the most common bycatch species are the southern banded guitarfish, Zapteryx xyster Jordan \& Everman 1896, and the Velez ray or rasptail skate, Raja velezi Chirichigno 1973, account for 10.9 and $20.9 \%$ of the total elasmobranch bycatch, respectively (Clarke et al. 2016). There is, however, no published information available of their reproductive cycles throughout their geographic distributions.

Z. xyster is distributed southeast from the Gulf of California to Peru (Compagno 1999), from shallow waters to $150 \mathrm{~m}$ deep (Bussing \& López 1993). It reaches a maximum total length (TL) of $78.3 \mathrm{~cm}$, with females maturing at 47.0-52.0 $\mathrm{cm}$ TL and males at 42.0-47.0 cm TL (Clarke et al. 2014). Casper et al. (2009) reported Z. xyster to be viviparous. The geographic distribution of $R$. velezi ranges from the Gulf of California to Peru (Ruiz-Campos et al. 2010), and it is commonly found at depths from $35-300 \mathrm{~m}$ (Grove \& Lavenberg 1997). The species attains a maximum size of $80 \mathrm{~cm}$ TL, with females maturing at $53.0-58.0 \mathrm{~cm}$ TL and males at $57.5-60.5 \mathrm{~cm}$ TL (Navia et al. 2007, Clarke et al. 2014). Dulvy \& Reynolds (1997) reported this species to be oviparous.

Both $Z$. xyster and R. velezi are endemic to the ETP (Compagno 1999, Ruiz-Campos et al. 2010) and listed as data deficient by the International Union of Conservation of Nature (IUCN) (Casper et al. 2009, Valenti \& Kyne 2009). Previous studies have shown that commercial trawling grounds in the ETP overlap with habitats of $Z$. xyster and $R$. velezi (Clarke et al. 2016, 2018), and therefore, these batoids are vulnerable to fishing pressure. Information on their reproductive cycles is essential to define appropriate conservation and management strategies (Rojas 2006, Clarke et al. 2014, Zanella \& López-Garro 2015, Espinoza et al. 2018). We studied the reproductive cycles of $Z$. xyster and $R$. velezi, two tropical endemic batoids in the ETP, according to the classification of Wourms (1977), and discussed how the available life-history information for these species could be used in developing effective management policies.

\section{MATERIALS AND METHODS}

\section{Sampling}

Specimens of Zapteryx xyster and Raja velezi were collected by commercial shrimp bottom-trawl vessels along the Pacific continental shelf of Costa Rica (Fig. 1). Samples were obtained at depths ranging from $25-$ $350 \mathrm{~m}$ between February 2010 and September 2011 using two epibenthic nets $(20.5 \mathrm{~m}$ length, $5.35 \times 0.85 \mathrm{~m}$ opening, $4.45 \mathrm{~cm}$ mesh size, $3.0 \mathrm{~cm}$ cod-end mesh size). Specimens were sexed, measured (total length, from the point of the snout to the end of the tail; disc width, distance between wing tip to wing tip; $\mathrm{cm}$ ), and weighed (total weight; $\mathrm{kg}$ ). All the specimens were frozen and transported to the laboratory for further analysis.

\section{Reproductive biology}

Maturity was assessed according to macroscopic characteristics, following the criteria used by Clarke et al. (2014). Females were classified as 1) neonates, when the reproductive tract was not developed, and the umbilical scar was open (this just in the case of $Z$. xyster); 2) juveniles, when small, translucent oocytes were present in the ovary, the oviductal gland was undeveloped, and uteri were thin, with no venation; 3 ) mature adults, when well-developed yolky oocytes were present in the ovary, the oviductal gland was similar in size to the largest oocyte, and uteri were highly developed. Additionally, for Z. xyster, females with developing embryo present were classified as gravid, while for $R$. velezi, females with ova capsules present were classified as a bearing. Males were classified as 1) neonates, when the claspers were not calcified, and tips did not reach the distal end of the pelvic fins, and the umbilical scar was open (just in the case of Z. xyster); 2) juveniles, when claspers were not calcified, but tips surpassed the distal margin of the pelvic fins; 3 ) mature adults, when claspers were calcified.

The hepatosomatic index (HSI) and gonadosomatic index (GSI) were estimated for mature females and males of both species, according to Sulikowski et al. (2005). The HSI was calculated as the percentage of the body weight occupied by the liver (HSI $=$ liver $_{\text {wet weight }}$ / total body wet weight $\times 100$ ). Temporal trends of this index are used to describe the reproductive cycle, based on the assumption that lipids stored in the liver are used for reproduction (Rossouw 1987). The GSI was calculated as the percentage of the body occupied by the gonads $\left(\mathrm{GSI}=\right.$ gonads $_{\text {wet }}$ weight $/$ total body wet weight $\times$ 100). The GSI has been used extensively to determine variations in gonad development across time (Hamlett 1999). The reproductive cycle in mature females was also evaluated by measuring the oviductal gland width $\left(\mathrm{OG}_{\mathrm{W}} ; \mathrm{mm}\right)$ and the oocyte (yolk follicle) diameter $\left(\mathrm{YF}_{\mathrm{D}}\right.$; mean of the three largest follicles in each right and left ovary; $\mathrm{mm}$ ), since both measurements are related to females ovarian dynamics (Sulikowski et al. 2005). 


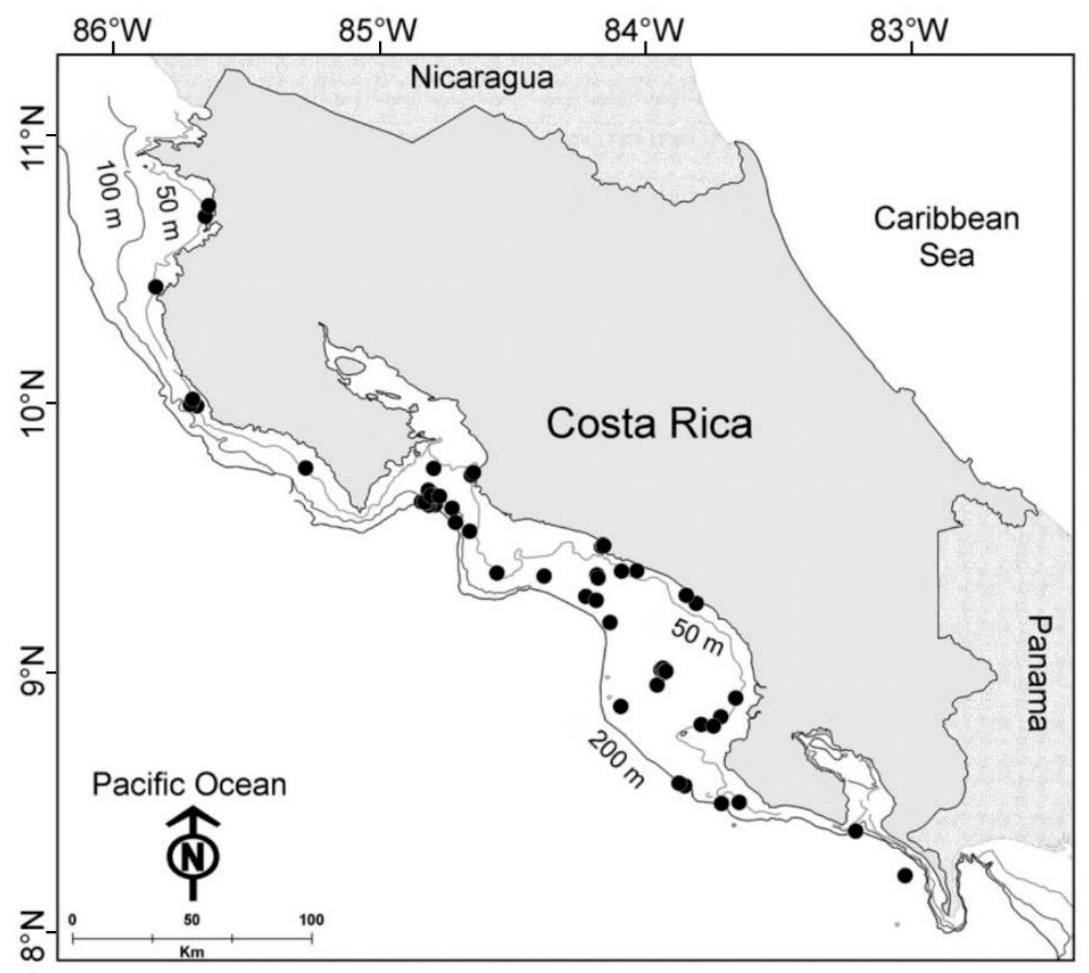

Figure 1. Sampling locations of Zapteryx xyster and Raja velezi caught as bycatch in the shrimp bottom-trawl fishery between 2010 and 2011 along the Pacific coast of Costa Rica.

\section{Data analysis}

The estimated values of HSI and GSI of both males and females, and $\mathrm{OG}_{\mathrm{W}}$ and $\mathrm{YF}_{\mathrm{D}}$ of females, of $Z$. xyster and $R$. velezi, were grouped in bimonthly periods for further analyses: December-January and February-March (dry season), April-May (transition from dry to the rainy season), June-July, August-September, OctoberNovember (rainy season), according to Amador et al. (2006). A bootstrapped ANOVA $(\alpha=0.05,10,000$ replicates) was used to detect possible temporal differences in HSI, GSI, OGW, and $\mathrm{YF}_{\mathrm{D}}$ (Ter Braak 1992, Archer et al. 1997). All the analyses were performed using the boot library (Davison \& Hinkley 1997, Canty \& Ripley 2016) in R (RStudio Team 2015). We classified the reproductive cycles, according to Wourms (1977).

\section{RESULTS}

\section{Reproductive cycle of Zapteryx xyster}

A total of 208 specimens of Z. xyster $(15.1-78.3 \mathrm{~cm}$ total length; 7.1-41.2 cm disc width; $14.8-2635 \mathrm{~g}$ total weight) were collected, of which $128(62 \%)$ were immature, and $80(38 \%)$ were mature. Of these, 24 $(11 \%)$ were males, and $56(27 \%)$ were females. The HSI of female Z. xyster did not present significant bimonthly variations $\left(\mathrm{F}_{6,86}=2.32 ; P>0.05\right.$, Fig. $\left.2 \mathrm{~b}\right)$; neither did the average $\mathrm{YF}_{\mathrm{D}}\left(\mathrm{F}_{3,80}=2.33 ; P>0.05\right.$; Fig. 3a) nor average $\mathrm{OG}_{\mathrm{W}}\left(\mathrm{F}_{5,84}=2.33 ; P>0.05\right.$; Fig. 3b). The GSI for females, however, did vary significantly $\left(\mathrm{F}_{6,85}=2.73 ; P<0.05\right)$, presenting a conspicuous peak in June-July 2010 (beginning of the rainy season) followed by a marked decrease during OctoberNovember 2010 (mid rainy season) (Fig. 2a). The GSI remained low until February-March 2011 (dry season), followed by another increase during April-May (transition from dry to rainy season), reaching the highest peak during June-July 2011 (beginning of the rainy season) (Fig. 2a). Gravid females were only recorded between December 2010 and March 2011 (dry season) (Fig. 4a). A total of 64 neonates of Z. xyster were collected during the study period (Fig. 4a). The highest proportion of neonates $(79 \%)$ was recorded at the beginning of the dry season (December 2010January 2011, Fig. 4a). Otherwise, males of $Z$. xyster showed no differences in HSI $\left(\mathrm{F}_{3,29}=3.47 ; P>0.05\right)$ nor GSI $\left(\mathrm{F}_{3,29}=3.47 ; P>0.05\right)$ during the study period (Fig. 2a-b).

\section{Reproductive cycle of Raja velezi}

A total of 629 specimens of $R$. velezi were collected (13.2-85.6 cm total length; $8.5-62.8 \mathrm{~cm}$ disc width, 7.8$2460 \mathrm{~g}$ total weight), of which 290 (46\%) were imma- 
a

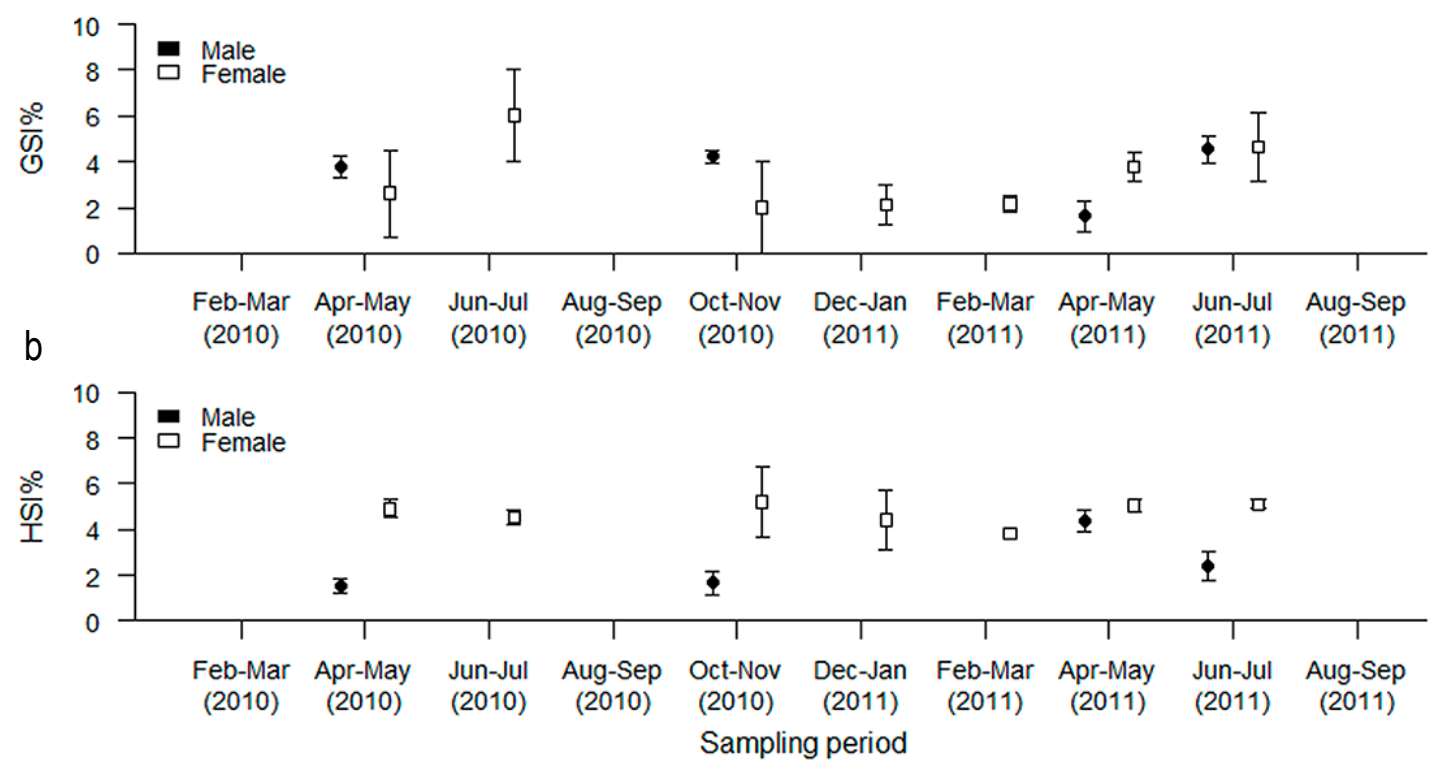

Figure 2. Bimestrial average and standard deviation of a) gonadosomatic index (GSI) and b) hepatosomatic index (HIS) in males (black) and females (white) of Zapteryx xyster from the Costa Rican Pacific coast (2010-2011).

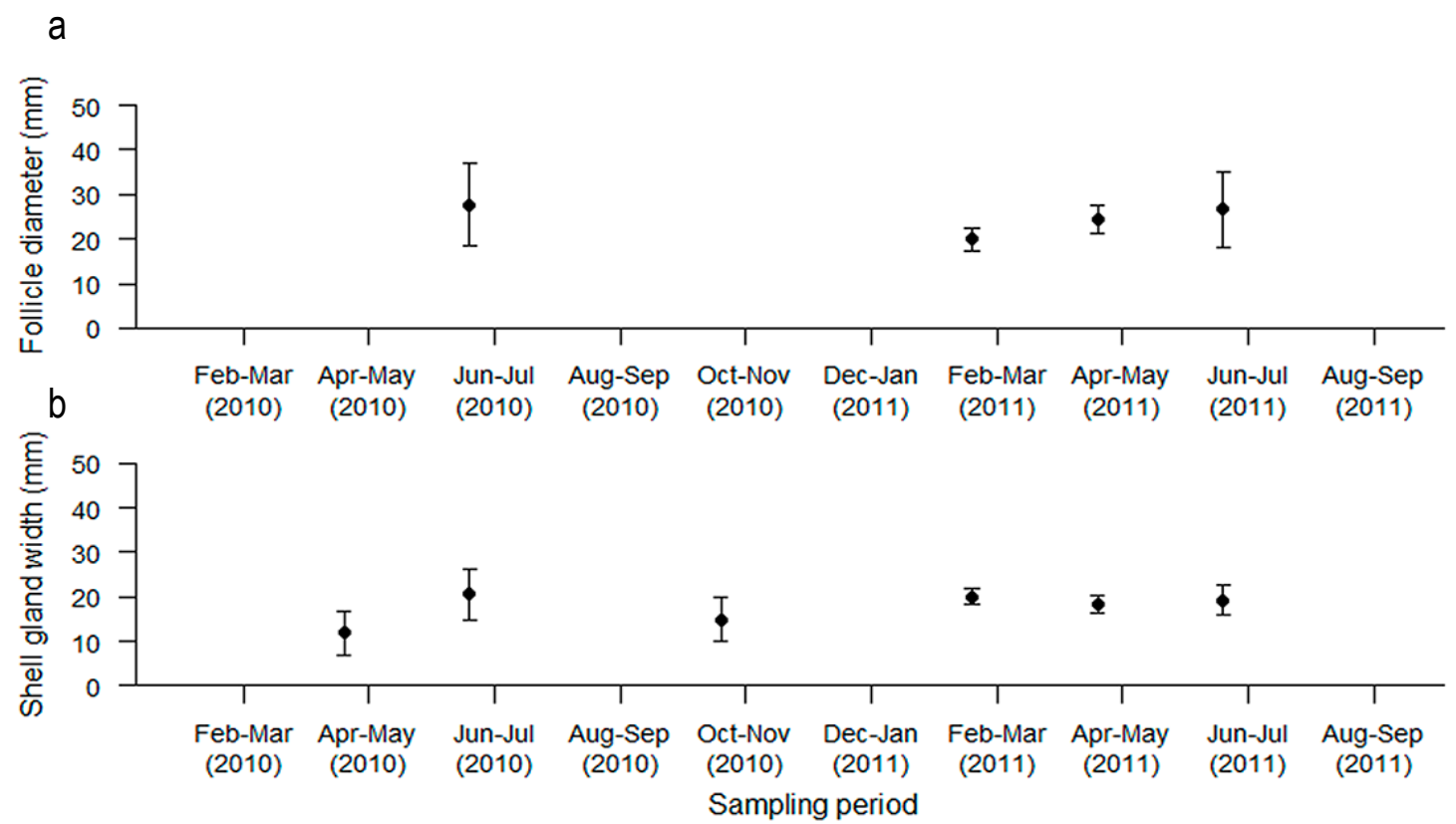

Figure 3. Bimestrial average and standard deviation of a) follicle diameter ( $\mathrm{mm})$, and b) oviductal gland width (mm) in females of Zapteryx xyster from the Costa Rican Pacific coast (2010-2011).

ture, 339 (54\%) were mature, of which 189 (30\%) were males and 150 (24\%) were females. The females of $R$. velezi exhibited no bimonthly variations in $\mathrm{HSI}\left(\mathrm{F}_{7,114}\right.$ $=2.09 ; P>0.05$, Fig. 5b), GSI $\left(\mathrm{F}_{7,107}=2.10 ; P>0.05\right.$, Fig. 5a), average $\mathrm{YF}_{\mathrm{D}}\left(\mathrm{F}_{7,102}=2.60 ; P>0.05\right.$, Fig. 6a) nor average $\mathrm{OG}_{\mathrm{W}}\left(\mathrm{F}_{7,104}=2.59 ; P>0.05\right.$, Fig. 6b). Eggbearing females were collected several times throughout the study period: February-May 2010,
December-May 2010, and October-November 2011 (Fig. 4b). Additionally, neonate's $R$. velezi were only captured between October 2010 and March 2011 (from the rainy season to the dry season) (Fig. 4b). Males of R. velezi showed no difference in $\mathrm{HSI}\left(\mathrm{F}_{7,117}=2.09 ; P\right.$ $>0.05$, Fig. $5 \mathrm{~b})$ or $\operatorname{GSI}\left(\mathrm{F}_{7,121}=2.08 ; P>0.05\right.$, Fig. 5a) between sampling periods. 


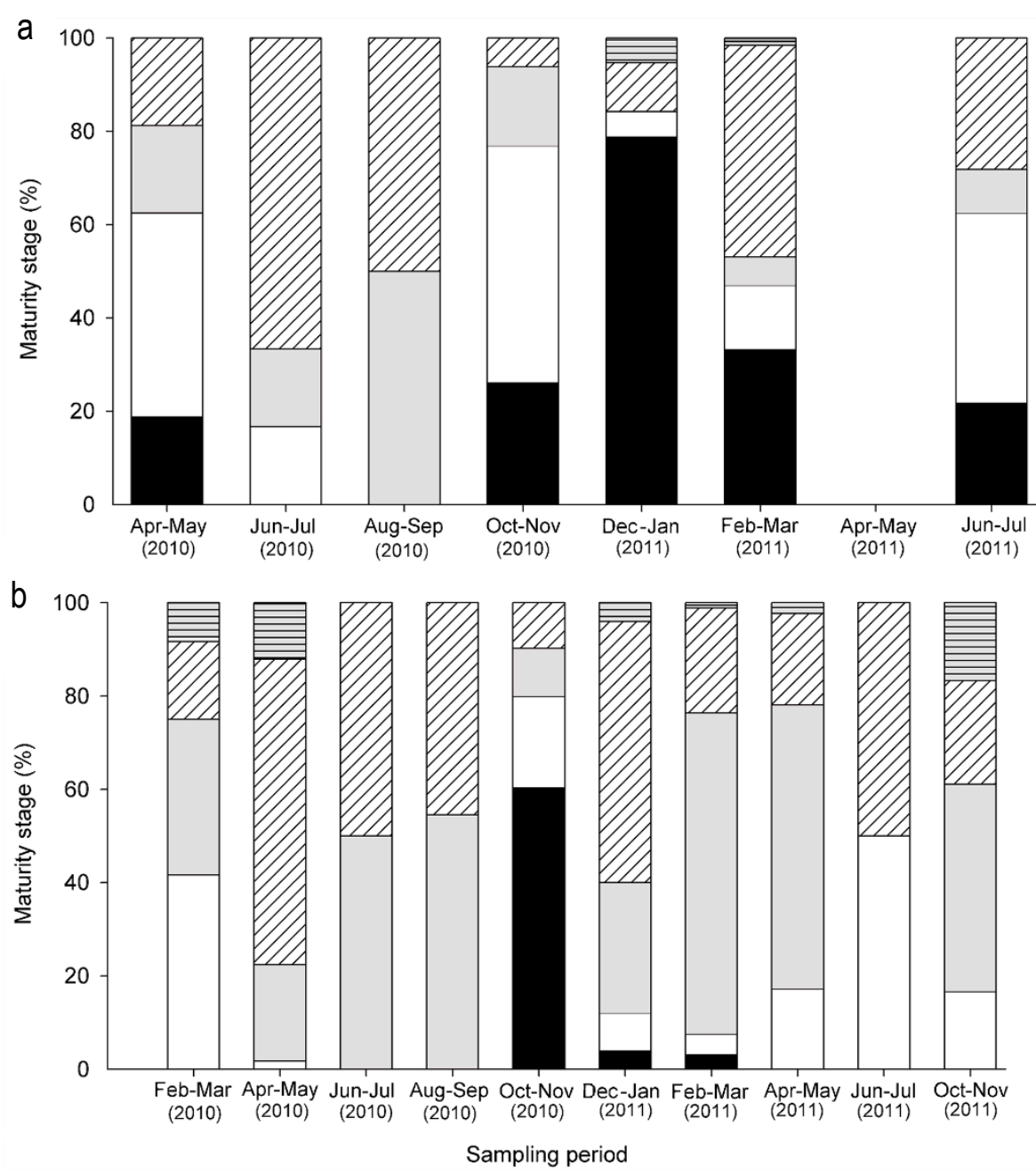

Figure 4. Bimestrial percentage of individuals per maturity stage of a) Zapteryx xyster and b) Raja velezi from the Costa Rican Pacific coast (2010-2011). Black: neonates; white: juveniles; gray: mature males; diagonal line over white: adult females; horizontal lines over gray: gravid (Z. xyster)/egg-bearing (R. velezi) females.

\section{DISCUSSION}

\section{Reproductive cycle of Zapteryx xyster}

Our study results suggest that Z. xyster has a partially defined annual reproductive cycle with a single peak occurring between June and July. Up to $79 \%$ of $Z$. xyster neonates were observed during the dry season (December-January), with the remaining 21\% collected during the rainy season. These findings suggest that some females mate and give birth outside the main reproductive peak. A partially defined reproductive cycle has also been reported for Zapteryx exasperata (Jordan \& Gilbert 1880) from the west coast of Baja California and the Gulf of California (Table 1) (Villavicencio-Garayzar 1995, Blanco-Parra et al. 2009). On the other hand, a three-year reproductive cycle was reported for Zapteryx brevirostris (Müller \& Henle 1841) in the southwestern Atlantic Ocean (Table 1) (Colonello et al. 2011).

Mating and fertilization of female Z. xyster probably occur between June and July, as suggested by the GSI peak, whereas pupping occurred between December and January when many neonates were found. These results suggest that this species may have gestation periods lasting between four and six months, following the definition of the gestation period for sharks as the period from fertilization to birth (Mejía-Falla et al. 2012). The gestation period of $Z$. xyster is relatively short compared to the one-year gestation period of $Z$. brevirostris (Colonello et al. 2011), but similar to the 3-5 months gestation period of $Z$. exasperata (Villavicencio-Garayzar 1995, Blanco-Parra et al. 2009) (see details in Table 1). 


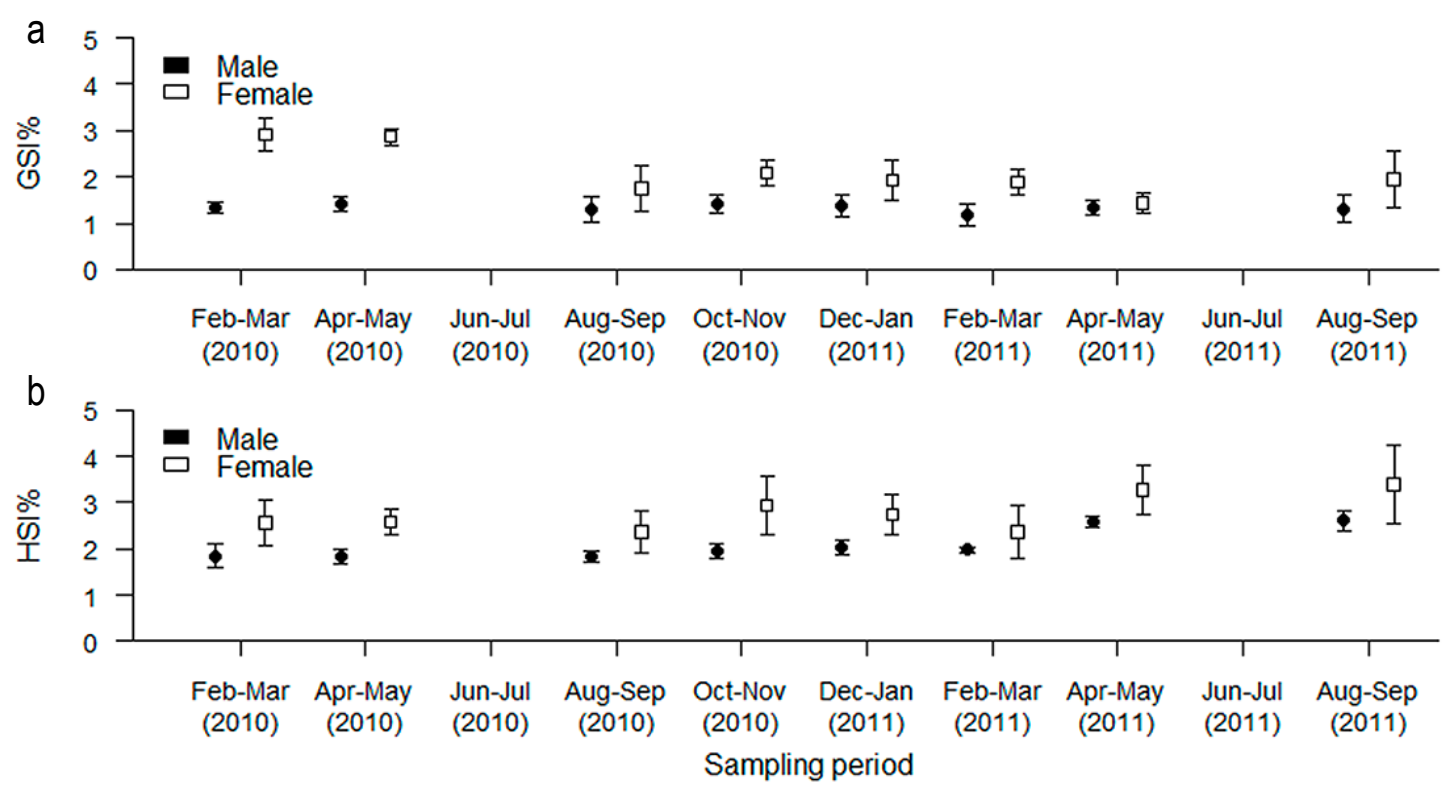

Figure 5. Bimestrial average and standard deviation of a) gonadosomatic index (GSI), and b) hepatosomatic index (HSI) in males (black) and females (white) of Raja velezi from the Costa Rican Pacific coast (2010-2011).

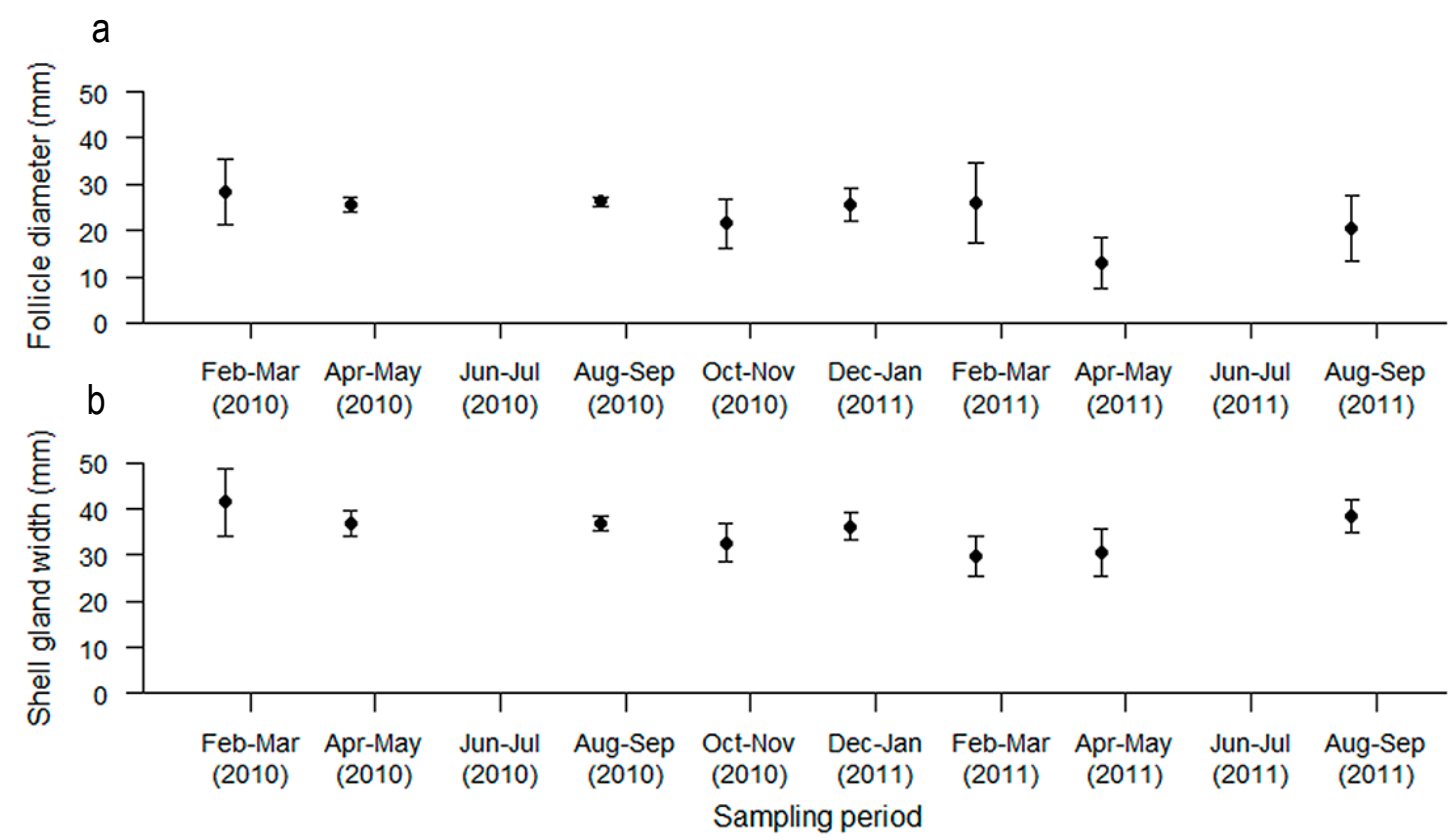

Figure 6. Bimestrial average and standard deviation of a) follicle diameter ( $\mathrm{mm}$ ), and b) shell gland width ( $\mathrm{mm}$ ) in females of Raja velezi from the Costa Rican Pacific coast (2010-2011).

Differences in reproductive cycles and gestation periods among Zapteryx species could be related, in part, to environmental gradients among their geographic distribution ranges. Specifically, the longer reproductive cycle reported for $Z$. brevirostris could be attributed to lower temperatures in the southwestern Atlantic Ocean. The higher temperatures throughout the distributions of $Z$. exasperata (Mexico) and $Z$. xyster (Costa Rica) could lead to faster growth rates and smaller adult sizes that would accelerate reproductive rates, including gestation periods. Several studies have demonstrated that variations in reproductive traits related to latitudinal gradients may occur even at the species level (Sulikowski et al. 2007a, Pérez-Jiménez \& Sosa-Nishizaki 2008, Driggers \& Hoffmayer 2009, Frisk $\&$ Miller 2009). For example, differences in repro- 
Table 1. Reproductive cycle, gestation period, maximum number of embryos, study site, and reference for three Zapteryx species.

\begin{tabular}{lccclll}
\hline Species & $\begin{array}{c}\text { Reproductive } \\
\text { cycle }\end{array}$ & $\begin{array}{c}\text { Gestation } \\
\text { period } \\
\text { months }\end{array}$ & $\begin{array}{c}\text { Maximum } \\
\text { number } \\
\text { of embryos }\end{array}$ & Study site & Reference \\
\hline Zapteryx brevirostris & Three years & One year & $1-2$ & Southwestern Atlantic Ocean, off Argentina & Colonello et al. (2011) \\
Zapteryx exasperata & One year & $3-4$ & - & West coast of Baja California & Villavicencio-Garayzar (1995) \\
Zapteryx exasperata & One year & 5 & 7 & Gulf of California & Blanco-Parra et al. (2009) \\
Zapteryx xyster & One year & $4-6$ & 8 & Costa Rica, Central America & Clarke et al. (2014), present study \\
\hline
\end{tabular}

ductive traits of the bonnethead shark Sphyrna tiburo (Linnaeus 1758) were reported among populations at Tampa Bay (warm-temperate conditions) and Florida Bay (tropical conditions), which could be associated with changes in the metabolism influenced by different temperature regimes (Parsons 1993). Although the effect of latitude on elasmobranch reproduction has been poorly studied (Parsons et al. 2008), there is growing evidence in other aquatic taxa that latitudinal clines, such as water temperature, can regulate the differences observed in life-history traits. For example, the Eurasian perch's growth rates and reproductive investment (Perca fluviatilis) decrease with latitude, while the life span, size, and age at maturity increase with latitude (Heibo et al. 2005). Similarly, females of several species of caridean and sicyoniid shrimps tend to have shorter periods in broods at lower latitudes than at higher latitudes (Bauer 1992). Both authors argue that latitudinal differences in these aquatic taxa are influenced by temperature, which strongly affects these organisms' growth and repro-duction (Bauer 1992, Heibo et al. 2005).

The litter size is positively correlated with the maximum size of females (Frisk 2010), then larger females tend to produce higher numbers of produced offspring. This relation is supported by data from three Zapteryx species (Table 1). Z. brevirostris produces the lowest number of embryos and has a more extended gestation period; conversely, Z. exasperata, and $Z$. xyster carry more embryos but generally have shorter gestation periods (Table 1). Z. brevirostris is the smallest species $(54.0 \mathrm{~cm}$ maximum TL, Bigelow \& Schroeder 1953) and has the lowest number of embryos, while both $Z$. exasperata and Z. xyster produce more embryos and reach a maximum TL of 90.0 (Blanco-Parra et al. 2009) and $78.3 \mathrm{~cm}$ (Clarke et al. 2014), respectively.

The description of elasmobranch reproductive cycles is often based on female gestation periods and ovarian cycles, and consequently, most studies do not include males in the reproductive cycle analysis (Carrier et al. 2004, Castro 2009). Our results revealed no evidence of reproductive seasonality in male $Z$. xyster. However, since we propose a partially defined annual reproductive cycle with one peak for females, and some females were reproductively active outside their main reproductive peak season, males are likely to mate continuously throughout the year. There are few studies on the male reproductive cycle of other batoid species in the ETP; for example, males of Z. exasperata with semen in the seminal vesicle and claspers were found only during the mating months (Blanco-Parra et al. 2009). In Urotrygon rogersi, mature males were found year-round; the highest proportion, however, was observed during female ovulation (Mejía-Falla et al. 2012). Additional studies on the male reproductive cycle of batoids are needed to better understand potential reproductive synchronicity in this species.

\section{Reproductive cycle of Raja velezi}

Our findings suggest that $R$. velezi has a continuous reproductive cycle with no apparent peaks throughout the year. All of the four reproductive parameters used to infer the reproductive cycle of $R$. velezi (HSI, GSI, $\mathrm{YF}_{\mathrm{D}}$, and $\mathrm{OG}_{\mathrm{W}}$ ) showed no evidence of reproductive seasonality. A continuous reproductive cycle means fertile females can be found throughout most of the year, and potentially the population can produce more offspring. Moreover, egg-bearing females and neonates were observed year-round. These findings are in agreement with similar observations in several other species of the family Rajidae: Amblyraja radiata (Donovan 1808) in the Gulf of Maine (Sulikowski et al. 2005), Atlantoraja cyclophora (Regan 1903) in Uruguay and Brazil (Oddone \& Vooren 2005, Oddone \& Velasco 2006, Orlando et al. 2011), Bathyraja albomaculata (Norman 1937) in southwestern Atlantic (Henderson et al. 2005, Ruocco et al. 2006), Leucoraja erinacea (Mitchill 1825) in Delaware Bay (Fitz \& Daiber 1963), Malacoraja senta (Garman 1885) in the Gulf of Maine (Sulikowski et al. 2007b), Beringraja binoculata (Girard 1855) in Gulf of Alaska (Ebert et al. 2008), Raja clavata Linnaeus 1758 in the Black Sea (Saglam \& Ak 2012), Beringraja rhina (Jordan \& 
Gilbert 1880) in Gulf of Alaska (Ebert et al. 2008), and Raja texana Chandler 1921 in the Gulf of Mexico (Williams et al. 2011). On the other hand, some skates, such as Rioraja agassizii (Müller \& Henle 1841) in Brazil, have conspicuous reproductive peaks (Oddone et al. 2007, Oddone \& Capapé 2011). In our study, the highest catches of neonates of $R$. velezi occurred during October-November 2010; no egg-bearing females, however, were caught during this period, probably related to the oviparous strategy of $R$. velezi, as females release their capsules well before neonates hatch (Dulvy \& Reynolds 1997).

\section{Management implications}

Both $Z$. xyster and $R$. velezi are commonly caught as bycatch by the semi-industrial trawl fishery in Central (Clarke et al. 2016) and South America (Mejía-Falla et al. 2006, Navia et al. 2007). These two batoids share a similar geographic distribution (Compagno 1999, RuizCampos et al. 2010, Clarke et al. 2014, 2016), bathymetric range (Bussing \& López 1993, Grove \& Lavenberg 1997), and have high dietary and isotopic niche overlap (Espinoza et al. 2012, 2013, 2015). Nonetheless, Z. xyster and R. velezi exhibit different reproductive cycles, and thus their vulnerability to fishing vary through time. For example, Z. xyster is probably more vulnerable to fishing during reproductive aggregations and recruitment (e.g. mating, gestation, and pupping) (Clarke et al. 2014, 2016), whereas $R$. velezi is not as vulnerable to fishing during reproductive aggregations because of their continuous reproductive cycle. Consequently, management approaches to protect these species cannot assume that they are subject to the trawl fishery's same time pressures. Also, sex segregation in both species has been observed, with males of $R$. velezi primarily occurring at deeper waters, while females of $Z$. xyster are more abundant at intermediate depths (Clarke et al. 2014). In both species, immature stages dominate in shallow waters (Clarke et al. 2014). Therefore, management measures should also consider protection in shallow waters to protect immature specimens.

Based on our results, conservation efforts for $Z$. xyster should focus on reducing the fishing pressure on its populations between June and July and during December and January, when the mating and pupping seasons are likely to occur, respectively. In contrast, conservation measures for $R$. velezi should focus on spatial protections on previously identified nursery grounds along the coast of Costa Rica (Clarke et al. 2014, 2016). These management measures could also help protect the other 23 elasmobranch species accidentally caught by the bottom-trawl fishery (Clarke et al. 2014).
This study provides the first information on the reproductive cycle of two endemic coastal elasmobranchs from the ETP, commonly caught in this region's trawl fisheries. Both species are currently classified as data deficient by the IUCN Red List (Casper et al. 2009, Valenti \& Kyne 2009). However, due to their life histories, spatial/temporal overlap with bottom-trawl fisheries, and the poor reporting and management in the ETP, they are considered to be highly vulnerable by more recent assessments (Dulvy et al. 2014, Clarke et al. 2018), indicating the need to update conservation status based on life-history traits.

\section{ACKNOWLEDGMENTS}

This research was partially funded by Conservation International, MarViva, Consejo Nacional de Ciencia y Tecnología de Costa Rica (CONICIT Project \#FI-44910), and Universidad de Costa Rica (Project \#808-B0536; 111-A4-508). The Rainbow Jewels S.A. greatly contributed by using their commercial shrimp trawlers for field work; we are grateful for the ONUVA crew members' collaboration. Fresia Villalobos greatly contributed to the early stages of this research. Thank Jaime Nivia for his field work assistance, Juliana Herrera, Beatriz Naranjo, Juan Vargas, Natalia Sandoval, Vivian Sanabria, Marcela Herrera, and Alberto Chacón for their collaboration and support during the fieldwork. We are also thankful for Raquel Romero's help in preparing the map.

\section{REFERENCES}

Amador, J.A., Alfaro, E.J., Lizano, O.G. \& Magaña, V.O. 2006. Atmospheric forcing of the eastern Tropical Pacific: a review. Progress in Oceanography, 69: 101142.

Archer, G.E.B., Saltelli, A. \& Sobol, I.M. 1997. Sensitivity measures, ANOVA-like techniques and the use of bootstrap. Journal of Statistical Computation and Simulation, 58: 99-120. doi: 10.1080/00949659 708811825

Awruch, C.A. 2013. Reproductive endocrinology in chondrichthyans: the present and the future. General and Comparative Endocrinology, 192: 60-70. doi: 0.1016/j.ygcen.2013.05.021

Bauer, R.T. 1992. Testing generalizations about latitudinal variation in reproduction and recruitment patterns with sicyoniid and caridean shrimp species. Invertebrate Reproduction and Development, 22: 193202. doi: 10.1080/07924259.1992.9672272

Bigelow, H.B. \& Schroeder, W.C. 1953. Sawfishes, guitarfishes, skates and rays. In: Tee-Van, J. (Ed.). Fishes of the western North Atlantic. Part II. Sears 
Foundation for Marine Research-Yale University, New Haven, pp. 1-514.

Blanco-Parra, M.P., Márquez-Farías, J.F. \& GalvánMagaña, F. 2009. Reproductive biology of the banded guitarfish, Zapteryx exasperata, from the Gulf of California, Mexico. Journal of the Marine Biological Association of the United Kingdom, 89: 1655-1662. doi: 10.1017/S0025315409990348

Bussing, W.A. \& López, M. 1993. Peces demersales y pelágicos costeros del Pacífico de Centro América meridional. Editorial Universidad de Costa Rica, San José.

Bussing, W.A. \& López, M. 2009. Marine fish. In: Wehrtmann, I.S. \& Cortés, J. (Eds.). Marine biodiversity of Costa Rica, Central America. Springer, Berlin, pp. 453-458.

Canty, A. \& Ripley, B. 2016. Boot: Bootstrap R (S-Plus) functions. R Package. R Foundation for Statistical Computing. [http://www.R-project.org]. Reviewed: April 14, 2020.

Carrier, C., Pratt, H.L. \& Castro, J.I. 2004. Reproductive biology of elasmobranchs. In: Carrier, C., Musick, J.A. $\&$ Heithaus, M.R. (Eds.). Biology of sharks and their relatives. CRC Press, Boca Raton, pp. 269-284.

Casper, B.M., Ebert, D.A. \& Kyne, P.M. 2009. The IUCN Red List Threatened Species: Zapteryx xyster. [http:// www.iucnredlist.org/details/60178/0]. Reviewed: April 14, 2020.

Castro, J.I. 2009. Observations on the reproductive cycles of some viviparous North American sharks. Aqua, 15: 205-222.

Chapman, D.D., Feldheim, K.A., Papastamatiou, Y.P. \& Hueter, R.E. 2015. There and back again: a review of residency and return migrations in sharks, with implications for population structure and management. Annual Review of Marine Science, 7: 547-570. doi: 10.1146/annurev-marine-010814-015730

Clarke, T., Espinoza, M. \& Wehrtmann, I.S. 2014. Reproductive ecology of demersal elasmobranchs from a data-deficient fishery, Pacific of Costa Rica, Central America. Fisheries Research, 157: 96-105. doi: 10.1016/j.fishres.2014.04.003

Clarke, T., Espinoza, M., Ahrens, R. \& Wehrtmann, I.S. 2016. Elasmobranch bycatch associated with the shrimp trawl fishery off the Pacific coast of Costa Rica, Central America. Fishery Bulletin, 114: 1-17. doi: 10.7755/FB.114.1

Clarke, T., Espinoza, M., Romero, R. \& Wehrtmann, I.S. 2018. Assessing the vulnerability of demersal elasmobranchs to a data-poor shrimp trawl fishery in Costa Rica, Eastern Tropical Pacific. Biological
Conservation, 217: 321-328. doi: 10.1016/j.biocon. 2017.11.015

Colonello, J.C., García, M.L. \& Menni, R.C. 2011. Reproductive biology of the lesser guitarfish Zapteryx brevirostris from the southwestern Atlantic Ocean. Journal of Fish Biology, 78: 287-302. doi: 10.1111/ j.1095-8649.2010.02864.x

Compagno, L.J.V. 1999. Checklist of living elasmobranchs. In: Hamlett, W.C. (Ed.). Sharks, skates, and rays: the biology of elasmobranch fishes. Hopkins University Press, Maryland, pp. 471-498.

Costello, C., Ovando, D., Hilborn, R., Gaines, S.D., Deschenes, O. \& Lester, S.E. 2012. Status and solutions for the world's unassessed fisheries. Science, 338: 517-520. doi: 10.1126/science. 1223389

Dapp, D., Arauz, R., Spotila, J.R. \& O’Connor, M.P. 2013. Impact of Costa Rican longline fishery on its bycatch of sharks, stingrays, bony fish and olive ridley turtles (Lepidochelys olivacea). Journal of Experimental Marine Biology and Ecology, 448: 228239. doi: 10.1016/j.jembe.2013.07.014

Davidson, L.N.K., Krawchuk, M.A. \& Dulvy, N.K. 2015. Why have global shark and ray landings declined: improved management or overfishing? Fish and Fisheries, 17: 1-21. doi: 10.1111/faf.12119

Davison, A. \& Hinkley, D. 1997. Bootstrap methods and their applications. Cambridge University Press, Cambridge.

Driggers, W.B. \& Hoffmayer, E.R. 2009. Variability in the reproductive cycle of finetooth sharks, Carcharhinus isodon, in the northern Gulf of Mexico. Copeia, 2009: 390-393. doi: 10.1643/CE-08-167

Dulvy, N.K. \& Reynolds, J.D. 1997. Evolutionary transitions among egg-laying, live-bearing and maternal inputs in sharks and rays. Proceedings of the Royal Society B: Biological Sciences, 264: 13091315. doi.org/10.1098/rspb.1997.0181

Dulvy, N.K., Fowler, S.L., Musick, J.A., Cavanagh, R.D., Kyne, M., Harrison, L.R., et al. 2014. Extinction risk and conservation of the world's sharks and rays. eLife, 3: 1-34. doi: 10.7554/eLife.00590.001

Ebert, D.A., Smith, W.D. \& Cailliet, G.M. 2008. Reproductive biology of two commercially exploited skates, Raja binoculata and $R$. rhina, in the western Gulf of Alaska. Fisheries Research, 94: 48-57. doi: 10.1016/j.fishres.2008.06.016

Espinoza, M., Clarke, T.M., Villalobos-Rojas, F. \& Wehrtmann, I.S. 2012. Ontogenetic dietary shifts and feeding ecology of the rasptail skate Raja velezi and the brown smoothhound shark Mustelus henlei along the Pacific coast of Costa Rica, Central America. 
Journal of Fish Biology, 81: 1578-1595. doi: 10.1111/ j.1095-8649.2012.03410.x

Espinoza, M., Clarke, T.M., Villalobos-Rojas, F. \& Wehrtmann, I.S. 2013. Diet composition and diel feeding behaviour of the banded guitarfish Zapteryx xyster along the Pacific coast of Costa Rica, Central America. Journal of Fish Biology, 82: 286-305. doi: 10.1111/j.1095-8649.2012.03488.x

Espinoza, M., Díaz, E., Angulo, A., Hernández, S. \& Clarke, T.M. 2018. Chondrichthyan diversity, conservation status, and management challenges in Costa Rica. Frontiers in Marine Science, 5: 15 pp. doi: 10.3389/fmars.2018.00085

Espinoza, M., Munroe, S.E.M., Clarke, T.M., Fisk, A.T. \& Wehrtmann, I.S. 2015. Feeding ecology of common demersal elasmobranch species in the Pacific coast of Costa Rica inferred from stable isotope and stomach content analyses. Journal of Experimental Marine Biology and Ecology, 470: 12-25. doi: 10.1016/j. jembe.2015.04.021

Ferretti, F., Worm, B., Britten, G.L., Heithaus, M.R. \& Lotze, H.K. 2010. Patterns and ecosystem consequences of shark declines in the ocean. Ecology Letters, 13: 1055-1071. doi: 10.1111/j.1461-0248. 2010.01489. $\mathrm{x}$

Fitz, E.S.J. \& Daiber, F.C. 1963. An introduction to the biology of Raja eglanteria Bosc, 1802 and Raja erinacea Mitchill, 1825 as they occur in Delaware Bay. Bulletin of the Bingham Oceanographic Collection, 18: 69-97.

Frisk, M.G. 2010. Life-history strategies of batoids. In: Carrier, J.C., Musick, J.A. \& Heithaus, M.R. (Eds.). Sharks and their relatives. CRC Press, Boca Raton, pp. 283-316.

Frisk, M.G. \& Miller, T.J. 2009. Maturation of little skate and winter skate in the western Atlantic from Cape Hatteras to Georges Bank. Marine and Coastal Fisheries: Dynamics, Management, and Ecosystem Science, 1: 1-11. doi: 10.1577/C08-014.1

Goldman, K.J., Cailliet, G.M., Andrews, A.H. \& Natanson, L.J. 2012. Assessing the age and growth of chondrichthyan fishes. In: Carrier, J.C., Musick, J.A. \& Heithaus, M.R. (Eds.). Biology of sharks and their relatives. Taylor \& Francis Group, Boca Raton, pp. 423-451.

Graham, N.A.J., Spalding, M.D. \& Sheppard, C.R.C. 2010. Reef shark declines in remote atolls highlight the need for multi-faceted conservation action. Aquatic Conservation: Marine and Freshwater Ecosystems, 20: 543-548. doi: 10.1002/aqc.1116C

Grove, J.S. \& Lavenberg, R.J. 1997. The fishes of the Galápagos Islands. Stanford University Press, California.
Hamlett, W.C. 1999. Male reproduction system. In: Hamlett, W.C. (Ed.). Sharks, skates, and rays: the biology of elasmobranch fishes. Johns Hopkins University Press, Maryland, pp. 444-470.

Heibo, E., Magnhagen, C. \& Vøllestad, L.A. 2005. Latitudinal variation in life-history traits in Eurasian perch. Ecology, 86: 3377-3386. doi: 10.1890/04-1620

Henderson, A.C., Arkhipkin, A.I. \& Chtcherbich, J.N. 2005. Distribution, growth and reproduction of the white-spotted skate Bathyraja albomaculata (Norman, 1937) around the Falkland Islands. Journal of Northwest Atlantic Fishery Science, 35: 79-87. doi: 10.2960/J.v35.m503

Heupel, M.R., Carlson, J.K. \& Simpfendorfer, C.A. 2007. Shark nursery areas: concepts, definition, characterization and assumptions. Marine Ecology Progress Series, 337: 287-297. doi: 10.3354/meps337287

Hoenig, J.M. \& Gruber, S.H. 1990. Life-history patterns in the elasmobranchs: implications for fisheries management. In: Pratt, H.L., Gruber, S.H. \& Taniuchi, T. (Eds.). Elasmobranchs as living resources: advances in the biology, ecology, systematics, and the status of the fisheries. NOAA Technical Report 90. NOAANational Marine Fisheries Sevice, Springfield, pp. 116.

Jirik, K.E. \& Lowe, C.G. 2012. An elasmobranch maternity ward: female round stingrays Urobatis halleri use warm, restored estuarine habitat during gestation. Journal of Fish Biology, 80: 1227-1245. doi: 10.1111/j.1095-8649.2011.03208.x

Mejía-Falla, P.A., Navia, A.F. \& Cortés, E. 2012. Reproductive variables of Urotrygon rogersi (Batoidea: Urotrygonidae): a species with a triannual reproductive in the eastern Tropical Pacific Ocean. Journal of Fish Biology, 80: 1246-1266. doi: 10.1111/j.1095-8649.2012.03237.x

Mejía-Falla, P.A., Navia, A.F. \& Giraldo, A. 2006. Notas biológicas de la raya ocelada Zapteryx xyster Jordan \& Evermann, 1896 (Chondrichthyes: Rhinobatidae) en la zona central de pesca del Pacífico colombiano. Investigaciones Marinas, Valparaíso, 34: 181-185.

Morgan, M.J. \& Hoenig, J.M. 1997. Estimating maturityat-age from length stratified sampling. Journal of Northwest Atlantic Fishery Science, 21: 51-63.

Navia, A.F., Mejía-Falla, P.A. \& Giraldo, A. 2007. Feeding ecology of elasmobranch fishes in coastal waters of the Colombian eastern Tropical Pacific. BMC Ecology, 7: 8. doi: 10.1186/1472-6785-7-8

Oddone, M. \& Capapé, C. 2011. Annual fecundity Rioraja agassizi neotropical southeastern Brazil. Brazilian Journal of Oceanography, 59: 277-279. doi: 10.1590/ S1679-87592011000300008 
Oddone, M. \& Velasco, G. 2006. Relationship between liver weight, body size and reproductive activity in Atlantoraja cyclophora (Elasmobranchii: Rajidae: Arhynchobatinae) in oceanic waters off Rio Grande do Sul, Brazil. Neotropical Biology and Conservation, 1: 12-16.

Oddone, M. \& Vooren, C. 2005. Reproductive biology of Atlantoraja cyclophora (Regan 1903) (Elasmobranchii: Rajidae) off southern Brazil. ICES Journal of Marine Science, 62: 1095-1103. doi: 10.1016/j. icesjms.2005.05.002

Oddone, M.C., Amorim, A.F., Mancini, P.L., Norbis, W. \& Velasco, G. 2007. The reproductive biology and cycle of Rioraja agassizi (Müller and Henle, 1841) (Chondrichthyes: Rajidae) in southeastern Brazil, SW Atlantic Ocean. Scientia Marina, 71: 593-604. doi: 10.3989/scimar.2007.71n3593

Orlando, L., Pereyra, I., Paesch, L. \& Norbis, W. 2011. Size and sex composition of two species of the genus Atlantoraja (Elasmobranchii, Rajidae) caught by the bottom trawl fisheries operating on the Uruguayan continental shelf (southwestern Atlantic Ocean). Brazilian Journal of Oceanography, 59: 357-364. doi: 10.1590/S1679-87592011000400006

Parsons, G.R. 1993. Geographic variation in reproduction between two populations of the bonnethead shark, Sphyrna tiburo. Environmental Biology of Fishes, 38: 25-35.

Parsons, G.R., Hoffmayer, E.R., Hendon, J.M., BetSayad, W.V, Rocha, M.J., Arukwe, A. \& Kapoor, B.G. 2008. A review of shark reproductive ecology: life history and evolutionary implications. In: Rocha, M.J., Arukwe, A. \& Kapoor, B.G. (Eds.). Fish reproduction. CRC Press, Boca Raton, pp. 435-469.

Pérez-Jiménez, J.C. \& Sosa-Nishizaki, O. 2008. Reproductive biology of the brown smoothhound shark Mustelus henlei, in the northern Gulf of California, Mexico. Journal of Fish Biology, 73: 782792. doi: $10.1111 / \mathrm{j} .1095-8649.2008 .01939 . \mathrm{x}$

Rigby, C.L., White, W.T., Smart, J.J. \& Simpfendorfer, C.A. 2016. Life histories of two deep-water Australian endemic elasmobranchs: argus skate Dipturus polyommata and eastern spotted gummy shark Mustelus walkeri. Journal of Fish Biology, 88: 11491174. doi: 10.1111/jfb. 12891

Rojas, J.R. 2006. Reproducción y alimentación del tiburón enano Mustelus dorsalis (Pisces: Triakidae) en el Golfo de Nicoya, Costa Rica: elementos para un manejo sostenible. Revista de Biología Tropical, 54: 861-871.

Rossouw, G. 1987. Function of the liver and hepatic lipids of the lesser sand shark Rhinobatos annulatus (Müller \& Henle). Comparative Biochemistry and Physiology - Part B: Biochemistry \& Molecular Biology, 86: 785790. doi: 10.1016/0305-0491(87)90225-2
RStudio Team. 2015. RStudio: integrated development for R. RStudio Inc. [http://www.rstudio.com]. Reviewed: April 14, 2020.

Ruiz-Campos, G., Castro-Aguirre, J.L., Balart, E.F., Campos-Dávila, L. \& Vélez-Marín, R. 2010. New specimens and records of chondrichthyan fishes (Vertebrata: Chondrichthyes) off the Mexican Pacific coast. Revista Mexicana de Biodiversidad, 81: 363371.

Ruocco, N.L., Lucifora, L.O., Díaz de Astarloa, J.M. \& Wöhler, O. 2006. Reproductive biology and abundance of the white-dotted skate, Bathyraja albomaculata, in the southwest Atlantic. ICES Journal of Marine Science, 63: 105-116. doi: 10.1016/ j.icesjms.2005.08.007

Saglam, H. \& Ak, O. 2012. Reproductive biology of Raja clavata (Elasmobranchii: Rajidae) from southern Black Sea coast around Turkey. Helgoland Marine Research, 66: 117-126. doi: 10.1007/s10152-0110252-5

Spaet, J.L.Y., Nanninga, G.B. \& Berumen, M.L. 2016. Ongoing decline of shark populations in the eastern Red Sea. Biological Conservation, 201: 20-28. doi: 10.1016/j.biocon.2016.06.018

Sulikowski, J.A., Driggers, W.B., Ford, T.S., Boonstra, R.K. \& Carlson, J.K. 2007a. Reproductive cycle of the blacknose shark Carcharhinus acronotus in the Gulf of Mexico. Journal of Fish Biology, 70: 428-440. doi: 10.1111/j.1095-8649.2007.01314.X

Sulikowski, J.A., Elzey, S., Kneebone, J., Jurek, J., Howell, W.H. \& Tsang, P.C.W. 2007b. The reproductive cycle of the smooth skate, Malacoraja senta, in the Gulf of Maine. Marine and Freshwater Research, 58: 98-103. doi: 10.1071/MF05178

Sulikowski, J.A., Kneebone, J., Elzey, S., Jurek, J., Danley, P.D., Howell, W.H. \& Tsang, P.C.W. 2005. The reproductive cycle of the thorny skate (Amblyraja radiata) in the western Gulf of Maine. Fishery Bulletin, 103: 536-543.

Ter Braak, C.J.F. 1992. Permutation versus bootstrap significance tests in multiple regression and ANOVA. In: Jöckel, K.H., Rothe, G. \& Sendler, W. (Eds.). Bootstrapping and related techniques. Springer, Berlin, pp. 79-85.

Tobin, A.J., Mapleston, A., Harry, A.V. \& Espinoza, M. 2014. Big fish in shallow water: use of an intertidal surf-zone habitat by large-bodied teleosts and elasmobranchs in tropical northern Australia. Environmental Biology of Fishes, 97: 821-838. doi: 10.1007/s10641-013-0182-y

Valenti, S.V \& Kyne, P.M. 2009. The IUCN Red List of Threatened Species 2009: Raja velezi. [http://www. iucnredlist.org/details/161344/0]. Reviewed: April 14, 2020. 
Villavicencio-Garayzar, C.J. 1995. Reproductive biology of the banded guitarfish, Zapteryx xyster (Pisces: Rhinobatidae) in Bahía Almejas, Baja California Sur, Mexico. Ciencias Marinas, 21: 141-135.

Ward-Paige, C.A., Mora, C., Lotze, H.K., PattengillSemmens, C., McClenachan, L., Arias-Castro, E. \& Myers, R.A. 2010. Large-scale absence of sharks on reefs in the Greater Caribbean: a footprint of human pressures. Plos One, 5: e11968. doi: 10.1371/journal. pone.0011968

Whoriskey, S., Arauz, R. \& Baum, J.K. 2011. Potential impacts of emerging mahi-mahi fisheries on sea turtle and elasmobranch bycatch species. Biological Conservation, 144: 1841-1849. doi: 10.1016/j.biocon. 2011.03.021

Received: May 11, 2020; Accepted: August 312020
Williams, L.J., Cicia, A.M., Pellegrin, G.B., Smith, K.M. \& Sulikowski, J.A. 2011. The reproductive cycle of the roundel skate Raja texana. Journal of Fish Biology, 79: 298-305. doi: 10.1016/j.biocon.2011.03.021

Worm, B., Davis, B., Kettemer, L., Ward-Paige, C.A., Chapman, D., Heithaus, M.R., et al. 2013. Global catches, exploitation rates, and rebuilding options for sharks. Marine Policy, 40: 194-204. doi: 10.1016/j. marpol.2012.12.034

Wourms, J.P. 1977. Reproduction and development in chondrichthyan fishes. American Zoologist, 17: 379410.

Zanella, I. \& López-Garro, A. 2015. Abundancia, reproducción y tallas del tiburón martillo Sphyrna lewini (Carcharhiniformes: Sphyrnidae) en la pesca artesanal de Golfo Dulce, Pacífico de Costa Rica. Revista de Biología Tropical, 63: 307-317. 